\title{
11. The limits of recognition
}

\section{Manuhuia Barcham}

The last 20 years have seen the indigenous peoples of Australia and New Zealand receive unprecedented levels of recognition. This process has involved the recognition of both their position as the indigenous peoples of these two countries and of the various historical injustices that had been visited upon them over the last 200 years. This recognition has in part been based on a desire to bring about justice for these indigenous peoples. This process has taken a number of different forms including the creation of the native title process in Australia and initiation of the Treaty settlement process in New Zealand. However, while these processes have led to a number of positive outcomes they have also opened up the opportunity for the emergence of new kinds of injustice. This chapter explores this phenomenon through the lens of the original Yorta Yorta ruling in 1998 and the fisheries settlement in New Zealand. Focusing on these two cases the chapter demonstrates the current limits of recognition of these two processes-limits based upon an inability to deal adequately with the issue of cultural change over time. In order to overcome these new problems of injustice we need to approach the issue of cultural change over time more seriously, and not necessarily equate change with a loss of identity or authenticity.

\section{The recognition of recognition}

In many respects the last 20 years has seen the issue of recognition become one of the pivotal concepts in social, political and legal theory in the Anglo-American world. ${ }^{1}$ Indeed Nancy Fraser has gone so far as to claim that in the 1990s the politics of recognition replaced the politics of redistribution (Fraser 1995). Moreover, this shift in theoretical circles from a politics of redistribution to a politics of recognition was accompanied by a broader shift in public policy in a number of these Anglo-American countries. The 1990s were thus marked by a shift in New Zealand and Australia in their legislative and public policy frameworks towards the recognition of the special character of their indigenous peoples and towards the recognition that injustices had been committed against those peoples. In both countries these acts of recognition were explicitly linked to issues of justice. ${ }^{2}$ More specifically these acts of recognition were concerned with overcoming issues of historical injustice and their ongoing negative consequences.

\footnotetext{
${ }^{1}$ There is a large and growing body of work on the issue of recognition in the social and political theory literature. For prominent examples of this literature see Taylor (1992) and more recently Fraser and Honneth (2003).

2 So, for example, in the Australian case see Mabo $v$ Queensland (No. 2) [1992] 175 CLR 1 at 29.
} 
In New Zealand these processes were based on a growing recognition of the legitimacy of the Treaty of Waitangi while in Australia these processes flowed on from the recognition, in the Mabo case, that Australia was not terra nullius in 1788 at the imposition of British sovereignty. In New Zealand and Australia practical steps flowing on from this act of recognition led to, amongst other things, the creation of the Treaty settlement process and the native title process respectively. It is to an analysis of these two processes that we now turn.

\section{Justice from recognition}

Various Māori protest movements and successful court cases brought by Māori groups against the Crown in the late 20th century led to the emergence of increasing recognition by the state (through the introduction of a number of key pieces of legislation) that Māori filled a special place in New Zealand society as tangata whenua (people of the land - that is, the indigenous people of New Zealand). In practice this recognition led to two main outcomes. The first was the emergence of the belief that wrongs committed against various Māori groups in the century and a half following the signing of the Treaty of Waitangi required restitution. ${ }^{3}$ One of the key aspects of this recognition was the creation of the Waitangi Tribunal - a quasi-judicial body. The Tribunal's main function is to conduct inquiries and make recommendations on the basis of those inquiries for issues relating to breaches of the Treaty of Waitangi. ${ }^{4}$ This then was the birth of the Treaty settlement process. The second outcome of this recognition, flowing on from the first, was that government policy and legislation increasingly came to contain specific reference to Māori and Māori groups. The last decades of the 20th century thus saw a dramatic sea-change in government's attitude to Māori that was predicated on the recognition of the continuing force of the Treaty of Waitangi and the subsequent recognition of the special status of Māori in New Zealand society. While these two processes were inter-related, I will focus in this chapter more on the issues which have flowed from the Treaty settlement process although some discussion of the broader social policy framework within which these events occurred will also be necessary.

Throughout the 1980s and 1990s the Waitangi Tribunal was kept busy with processing increasing numbers of claims. These claims spanned a wide number of issues stretching from the return of confiscated lands through to the challenging of government legislation concerning the sale and privatisation of

\footnotetext{
3 The initial Treaty of Waitangi Act 1975 allowed claims to be considered only for acts after the passage of this piece of legislation. However, the passage a decade later of the Treaty of Waitangi Amendment Act 1985 meant that claims were able to be considered dating back to the signing of the Treaty of Waitangi in 1840 .

4 It should be noted that the findings of the Tribunal are only recommendations and have no binding force in law.
} 
government assets. ${ }^{5}$ By the mid-1990s not only had a large number of claims been successfully processed, but sizeable quantities of money and resources had also begun to be transferred back to claimants as the New Zealand government began to act on the findings of the Waitangi Tribunal. The Ngāi Tahu and Tainui claims have been the largest and most prominent of these settlements to date. Both claims involved cash settlements approaching NZ\$200 million as well as the direct transfer of other resources such as land and an apology by the government for past wrongs committed. The operation of the Treaty settlement process over the last 20 years has thus seen the New Zealand government actively addressing past injustices through a process of recognition.

Paralleling the rise of the Treaty settlement process in New Zealand, the Mabo $v$ Queensland (No 2) 1992 High Court decision in Australia established that Australian common law recognised the existence of native title. This recognition was put into practical effect with the passage of the Native Title Act 1993 (Cwlth). The recognition of native title was hailed as a great move forward in addressing the injustices of Australia's colonial past. Referring to the principle of terra nullius in the Mabo (No 2) decision Justice Brennan argued that judged by any civilised standard, such a law is unjust and its claim to be part of the common law to be applied in contemporary Australia must be questioned. ${ }^{6}$ And, by the late 1990s, a number of positive native title determinations had been made, thereby helping to provide justice for those Aboriginal groups which had so long been denied title to their traditional lands. However, despite these initial successes in both New Zealand and Australia, trouble loomed on the horizon as the limits of the recognition offered in Australia and New Zealand to their respective indigenous peoples became clear.

\section{The limits of recognition}

In New Zealand, the first signs of trouble in the recognition process flowed from a 1992 government decision whereby Māori, in relinquishing their claims to fishing rights as recognised under earlier fisheries legislation, received NZ\$150 million of commercial fisheries assets and 20 per cent of all future fisheries allocations. ${ }^{7}$ In determining how these assets were to be distributed the Waitangi Fisheries Commission looked to iwi as the 'natural' recipients of these resources as it was thought that since the settlement was in exchange for fishing rights that had previously belonged to iwi then the settlement could only go to iwi (Barcham 2000: 145).

5 It should be noted that these claims were not all necessarily being lodged by traditional (or neo-traditional) Māori organisations. Indeed, the claim against the privatisation of government assets without prior Māori consultation (where Māori interests would have been affected by the sale) was brought against the government of the day by the New Zealand Māori Council—a modern non-tribal organisation which was itself a product of earlier government legislation.

6 Mabo v Queensland (No. 2) [1992] 175 CLR at 29.

7 In this following section I draw upon Barcham (2000). 
This determination was based around the generally held belief that traditionally Māori society had been organised along a framework of kin-based descent groups centred around three main units: whānau (immediate and extended family), hapu (clan), and iwi (confederation of hapū). When rangatira (chiefs) had signed the Treaty of Waitangi in 1840, they had signed in their capacity as leaders of hap $\bar{u}$ and iwi. The problem, in terms of the Fisheries settlement, flowed from the fact by the 1990s more than 80 per cent of Māori lived in urban areas and for many of these individuals $i w i$ and hapu were no longer seen as being the sole focal point of their identity as Māori (Maaka, 1997: 7). ${ }^{8}$ Nonetheless Māori in the urban environment still continued to identify as Māori. Thus while the Fisheries Commission looked to iwi as the most 'authentic' recipients of this settlement the extent to which this ideal matched the empirical reality was suspect. And so given the iwi-centric focus of both many Māori and New Zealand government departments in the 1990s, while no-one argued that Māori living in an urban environment were not entitled to receive these entitlements, both the Waitangi Fisheries Commission and $i w i$ themselves argued that urban Māori should receive these entitlements through iwi. However, groups representing urban Māori, such as the Manukau Urban Māori Authority (MUMA) and Te Whānau o Waipareira Trust, argued that all Māori possessed rights to this particular settlement and they should be entitled to claim them through whatever organisational structure they wished - be it iwi or a more modern structure such as MUMA.

The last years of the 1990s and first years of the new millennium were thus marked by a number of acrimonious court battles between representatives of iwi groups and representatives of urban Māori groups as they argued over who was entitled to a share of the cash and assets from the fisheries settlement. The underlying argument was whether or not an iwi could be identified as 'a people' or only as a specific 'traditional' organisational structure. The problem was, however, that even the modern iwi structures of the late 20th and early 21 st centuries were themselves relatively recent neo-traditional corporate constructs which had emerged in response to the changing government policy environment of the last two decades of the 20th century. 9 And so, although these iwi were seen by government as being the legitimate successors of the $i w i$ of the nineteenth century they were not identical with those first iwi.

8 In 1936, 81 per cent of the Māori population lived in their tribal areas, which more often than not were rural. Another problem with the decision to transfer these resources to iwi is that, as Angela Ballara has convincingly shown (1998), the idea that iwi were the main organisational form of Māori society appears to be a belief that emerged in the late 19th century. In a sense hapu dropped out of the equation - although recent battles over resources (once again concerning the Fisheries settlement) have seen the relationship between hapu and iwi come to the fore.

${ }^{9}$ For a more detailed discussion of these processes see Barcham (1998: 305-6). 
In these court battles we see how the justice brought about by the recognition of Māori claims was in turn leading to new and different forms of injustice. Māori were being denied access to settlements unless they chose to access those settlements through iwi structures. No recognition was made of the fact that historical circumstance had meant that many Māori no longer either saw iwi as their major source of identity or necessarily wanted to utilise these structures in their modern lives. And for some Māori in the urban environment the shift to the city (sometimes as much as four or five generations ago) meant that even if they had wanted to identify with an iwi they were no longer able to do so as they did not even know to which iwi their family belonged, although this did not in any way lessen their identity as Māori. The injustice therefore emerged from the inability of then current legal and policy frameworks to take seriously the changes that occurred in Māori society since the signing of the Treaty of Waitangi.

Similar problems have occurred in the Australian case. One of the key aspects of any determination of native title is the demonstration of an ongoing and unbroken normative existence of an Indigenous Australian community through the continued existence and practice of their lore and custom. For many groups this involves demonstrating that they reach a threshold of 'cultural authenticity' in terms of their continued normative existence as a group. While native title determinations for groups such as Martutjarra or the Spinifex People are relatively unproblematic in terms of passing this threshold of cultural authenticity, the Yorta Yorta case has shown that this is not the case for all Aboriginal communities.

In order to establish native title a claimant group has to fulfil three requirements. These conditions of recognition are that the claimant group: establish that they are the descendants from the original inhabitants of the territory in question; show their continued occupation of the land; and demonstrate the continued maintenance of their law and custom. In his original ruling on the Yorta Yorta case, Olney J argued that the Yorta Yorta people did not possess native title as:

the facts in this case lead inevitably to the conclusion that before the end of the 19th century the ancestors through whom the claimants claim title had ceased to occupy their traditional lands in accordance with their traditional laws and customs ... [As such,] the foundation of the claim to native title in relation to the land previously occupied by those ancestors having disappeared, the native title rights and interests previously enjoyed are not capable of revival. ${ }^{10}$

10 The members of the Yorta Yorta Aboriginal Community $v$ The State of Victoria \& Ors [1998] 1606 FCA (18 December 1998) s. 129. 
In reaching this decision Olney $\mathrm{J}$ based his argument on his belief that the tide of history has indeed washed away any real acknowledgment of their traditional laws and any real observance [by Yorta Yorta] of their traditional customs.'11

A number of points are to be noted in regards to this judgement. First, in coming to this conclusion, Olney $\mathrm{J}$ placed much more weight on the written evidence of the pastoralist E. M. Curr than he did on the oral evidence of Yorta Yorta individuals. $^{12}$ In doing this, apart from devaluing the importance of evidence from non-written sources, he explicitly argued that the cultural practices of the Yorta Yorta people of today (no matter how laudatory they were) did not match those of their ancestors as recorded in the Curr's writings. ${ }^{13}$

The key point to be noted here is that Olney was basing his decision on the belief that a group's present-day customs and laws needed to match those practiced by their ancestors at the imposition of British sovereignty (or at the least be strongly aligned - if not identical — with those recorded in the earliest written records) if native title was to be retained. That is, given the evidential weight that Olney J gave to the writings of E. M. Curr over the oral testimony of the current day descendants of the Yorta Yorta people, if native title by a group such as Yorta Yorta is to be achieved it now appears 'that contemporary observances [of their customs] must match the accounts we have of them in nineteenth century European documents' (Buchan 2002: s.12).

Effectively Olney $\mathrm{J}$ has argued that legal recognition of native title is dependent on the existence of an authentic form of Aboriginal culture; that is, an Aboriginal culture unchanged by contact with the west. In simple terms, he has argued that cultural change for Aboriginal groups extinguishes their native title. On one reading of the law-indeed this is how Olney read the precedents set by the case and statue law in the matter of native title - this may actually be the case, although this would involve a very strict and limited reading of the law. As I will argue later this narrow reading of the law is problematic in a number of ways.

However, even with a charitable reading of the decision, one would be hard pressed to understand Olney's claim in the Yorta Yorta case that 'no group or individual has been shown to occupy any part of the land in the sense that the original inhabitants can be said to have occupied it ${ }^{\prime 14}$ except in reference to a romanticised image of how Aboriginal Australians ought to live. In making this

\footnotetext{
11 The members of the Yorta Yorta Aboriginal Community $v$ The State of Victoria \& Ors [1998] 1606 FCA (18 December 1998) s. 129.

12 The members of the Yorta Yorta Aboriginal Community $v$ The State of Victoria \& Ors [1998] 1606 FCA (18 December 1998) S. 106.

13 The members of the Yorta Yorta Aboriginal Community $v$ The State of Victoria \& Ors [1998] 1606 FCA (18 December 1998) s. 123.

14 The members of the Yorta Yorta Aboriginal Community $v$ The State of Victoria \& Ors [1998] 1606 FCA (18 December 1998) s. 121.
} 
claim Olney $\mathrm{J}$ has effectively argued that to change the content of a group's law and customs is to change that group's identity. While this may be true, this is not always necessarily the case. While Yorta Yorta no longer practice all the various customs practised by their ancestors it does not necessarily mean that they identify any less as Yorta Yorta. Indeed, the counter-factual argument would not necessarily hold given that even if colonisation had not occurred, an environmental disaster may have caused just as radical a change in Yorta Yorta customs and law.

In making his decision in the Yorta Yorta case Olney $\mathrm{J}$ has raised the evidential 'bar' such that the majority of Aboriginal groups of eastern and southern Australia may never be able to achieve native title. ${ }^{15}$ In the Yorta Yorta case the quest for native title for some Australian Aboriginal groups is now dependent upon them matching an impossible standard of authentic traditional culture.

What we see emerging as a result of the Yorta Yorta case (and subsequent appeals) is a similar dynamic to that observed in New Zealand where an initial act of recognition has led to some instances of injustice. The key point from which this injustice flows is the inability of legal and policy frameworks to adequately deal with cultural change over time. That is, recognition within these frameworks appears to be dependent upon the maintenance of a fixed identity. In the Australian case this injustice means that some Aboriginal groups (such as Yorta Yorta) are, through the denial of the recognition of their native title rights, in a sense being denied their existence as authentic Aboriginal groups. Indeed, a Yorta Yorta woman Monica Morgan has recently gone so far as to say that the Yorta Yorta decision represents a form of bureaucratic genocide of her people (Morgan 2002: 4).

\section{Recognising change}

The key problem, as noted above, with the types of recognition of indigenous populations that have been achieved in Australia and New Zealand (and have formed the basis of the native title and Treaty settlement processes in these countries) is that these acts of recognition have been based on the maintenance of a prior identity by the group being recognised. This is problematic in a number of ways - most pressing being the inability for these strategies of recognition to adequately deal with the concept of change. As it stands the current frameworks mean that the content of the identity of the group being recognised must remain identical to that of the original group from which recognition flows if the current group's identity is to be recognised. As the Yorta Yorta case shows, deviation from an 'original' content is seen as reducing the authenticity of that identity and so too is seen as reducing the authenticity and legitimacy of their claim to recognition based on that identity.

15 See Lavery (2003). 
However, as has been briefly discussed above, this degree of the maintenance of a group's identity is something that has not been achieved even by groups generally seen by many as being extremely 'authentic'. Thus while modern iwi in New Zealand can, in many cases, be seen as the legitimate successors of the iwi of 19th century New Zealand, they are not identical with them. If anything, many of the modern corporate iwi structures in New Zealand more closely resemble a Western corporation than they do the descent groups of the past. Similarly the customs and lore followed by groups such as the Spinifex People who have achieved positive native title determinations are not identical to those of their ancestors. If this were the case then one would be hard pressed to understand the existence of particular lore and custom including cat dreaming (Cane 2002: 84). The problem thus appears not to lie in recognising change over time (for groups which have been recognised have indeed changed over time) but rather in terms of the extent of change undergone by the group in question.

\section{Dealing with change over time}

Different groups' cultures have adapted and changed (and continue to do so) dependent upon the environment within which they operate. ${ }^{16}$ Groups in the south east of Australia have had to accommodate higher degrees of contextual change than those groups who, for instance, live in the Western Desert. Contact with Europe and the wider world has meant that all indigenous groups in Australia and New Zealand (and elsewhere too one would imagine) have had to change the way in which they relate not only to the world but also to one another. This change in content does not, however, necessarily lead to a change in identity. ${ }^{17}$ And so, while the customs and laws of 21 st century English men and women do not match the customs of their 19th century predecessors this change in no way lessens the 'authenticity' of 21st century English men and women's identity as English.

However, in the Australian case this issue seems to stem, in part at least, from a particular approach to the issue of native title by some sections of the legal establishment. As discussed briefly above Olney's approach to the recognition of native title was dependent upon the existence of an authentic form of aboriginal culture - an argument which can be seen to flow from the original Mabo ruling which argued that 'native title has its origins in and is given its content by the traditional laws acknowledged by and the traditional customs observed by the indigenous inhabitants of a territory. ${ }^{18}$ However, this original argument in no way negates the possibility that cultures, and so too a society's

\footnotetext{
16 Indeed we could quite easily make the claim that change, in terms of adaptation to a changing external environment (be it physical or symbolic), is an inherent characteristic of culture.

17 This is not to say that change in content does not lead to change in identity. It is rather to make the different claim that this is not necessarily the case.

18 Mabo decision 1992, 42.
} 
lore, norms and traditions, can change over time. Olney's reading of the law was thus only one possible reading, a reading that focused on the equivalence of the customs of the present day descendants of the original native title holders with the customs of these original native title holders. In the Yorta Yorta case Olney $\mathrm{J}$ thus based his decision on the belief that 'the traditions and customs observed by Curr were said to constitute the title that burdened the Crown and it seems that only through continued observance of these particular customs would the title survive' (Strelein nd: 2). However, as Lisa Strelein has argued 'the radical title of the Crown at the time of the acquisition of sovereignty was burdened not by the native title rights and interests then existing, but was burdened by the fact of the existence of native title' (Strelein 2005: 69). And so, in the Australian case at least, problems associated with the inability of the native title process to adequately deal with questions of change stem not from the law itself but rather from its interpretation.

The New Zealand Māori case is slightly more complicated in that the identity in question - that of Māori (as opposed to descent groups such as hapu and iwi) is itself an artefact of contact between Māori and early European explorers. ${ }^{19}$ However, as I have noted elsewhere, many influential Māori leaders see no necessary contradiction between the fact that while the Treaty of Waitangi may have been signed with the representatives of hap $\bar{u}$ and $i w i$ it is urban Māori authorities that should receive some of the benefits of Treaty settlements (Barcham 1998: 308). In some respects the signing of the Treaty of Waitangi froze Māori society (at least in terms of the territorial bounds of hapu and iwi) at 1840. If the Treaty had been signed 10 years earlier or later then the Treaty settlement process would look considerably different as those 20 years saw the fortunes of a number of hap $\bar{u}$ and $i w i$ wax and wane quite considerably. However, despite this freezing process Māori society has continued to alter and change - the problem is that legislative frameworks have sometimes not taken this change into account.

\section{Taking change seriously}

What is required in New Zealand and Australia given the new forms of injustice that appear to be emerging from processes designed explicitly to bring about justice and right historical injustices, is that the process of change needs to be taken seriously. The problem is that the concept of change is a particularly difficult issue to accommodate in any legislative or policy framework as it necessarily entails a degree of uncertainty - and uncertainty is something of which bureaucratic and legal modes of organisation are not too fond. However,

\footnotetext{
19 In pre-European contact New Zealand, groups identifies themselves in terms of the descent groups to which they belonged. Māori (a verb used to describe a state of normalcy) as a term of identity was used by New Zealand's indigenous inhabitants so as to differentiate themselves from the early European explorers (who by any standards would have seemed most abnormal to these original inhabitants).
} 
just because particular frameworks do not easily adapt to change (the irony of this is clear) this does not mean that they cannot adapt. The Ward decision is a case in point of how change can be accommodated within a juridical framework. ${ }^{20}$

In their decision the Justices argued that in order to be traditional (as required under s. 223(1)(a) of the Native Title Act) the body of customs and law currently observed must originate and be given their content from the body of law and customs observed by the ancestors of the claimants. Now in making this claim the Justices acknowledged that some change or adaptation of law and custom over time would not necessarily be fatal to a native title claim. The problem, however, lay in assessing the degree and extent of change necessary for this change to be fatal to a native title claim. And so, as I noted above, the problem is not so much one of kind as it is one of degree.

To some extent then the issues I have discussed in this chapter are still to be overcome. However, precedents like the Ward case (in Australia at least) have opened up the space of possibility for a more serious engagement with issues of cultural change. The problem is not insurmountable, but overcoming it requires the realisation, by the legal fraternity at least, that issues of syncretism and authenticity are not inversely related. Early cases like the original Yorta Yorta case have unfortunately set a precedent in Australia where syncretism and adaptation are identified with assimilation - where, as has been shown above, this is not necessarily the case. Adaptation and assimilation are not necessarily linked. In New Zealand this link is not as strong as it is in Australia although it is still present. The process of recognition has thus still created an environment in New Zealand where non-traditional forms of Māori organisational form are devalued in the eyes of the courts at least. ${ }^{21}$

In many respects the problem is that people have been following the letter but not the spirit of the law in these processes of recognition. ${ }^{22}$ Those involved in these processes of recognition in Australia and New Zealand need to remember why these processes were initially created. They were created to overcome injustice. Given this, one cannot fall back on positivistic arguments as to the separation of moral and legal arguments. The statues under which these processes were established were created for precisely moral reasons and so one must approach one's deliberation of these issues with at least a certain degree of openness in their ethical sensibility rather than allowing one's judgement to be

\footnotetext{
20 The appropriateness of the 'bundle of rights' approach to native title being set to one side. For more on this see Glaskin (2003).

21 As noted above though, the 'authenticity' of modern iwi is itself a question that needs to be asked if questions of funding are dependent upon the authentic status of groups.

22 Although, as noted above, in the Australian case at least, there are a number of different ways in which the 'letter of the law' can be followed, some of which need not necessarily lead to new injustices being committed.
} 
clouded by outmoded and outdated 'folk' conceptions of what constitutes cultural change.

Where these processes become most problematic is where people's identity is shaped not by their own desires and will but instead by legislative and juridical processes. Indeed, this is where the worst injustices are being committed. The content of peoples' identities changes over time although this does not necessarily change one's identity. What I mean here, using the Yorta Yorta case as an example, is that while the present day Yorta Yorta people identify as Yorta Yorta they (I would imagine) would readily admit that the various customs and lore which shape and structure their lives as Yorta Yorta are not identical to those which shaped the lives of their Yorta Yorta ancestors yet they nonetheless still see themselves as being Yorta Yorta. Instead it merely changes the way through which their identity is constituted and/or performed. Problems have occurred when this process has been ignored or devalued. This is particularly unfortunate as current legislative frameworks are, as the Ward case as shown, able to deal with processes of change. And, perhaps most sadly, not doing so is leading to injustice for the indigenous peoples of these two countries - the exact thing that these processes of recognition were created to overcome. What we need to do then is approach these cases with an openness to the idea of the legitimacy of change.

\section{Conclusion}

In a sense both the native title and Treaty settlement process have been a success. Both processes were created through acts of recognition in order to overcome historical injustice. In this respect both processes have been successful as a number of these cases of historical injustice have been settled - if not overcome. However, the acts of recognition upon which these processes have been based have also led to new sources of injustice. In many respects these new forms of injustice flow from the inability for the issue of cultural change over time to be taken seriously by some engaged in these processes of recognition. What we need to do then is approach these processes of recognition in the spirit with which they were created. To do otherwise is to merely replace one form of injustice with another.

\section{References}

Ballara, A. 1998. Iwi: The Dynamics of Māori Tribal Organisation from c.1769 to c.1945, Victoria University Press, Wellington.

Barcham, M. 1998. 'The challenge of urban Māori: reconciling conceptions of indigeneity and social change', Asia Pacific Viewpoint, 39 (3): 303-14. 
Barcham, M. 2000. '(De)constructing the politics of indigeneity', in D. Ivison, P. Patton and W. Sanders (eds), Political Theory and the Rights of Indigenous Peoples, Cambridge University Press, Cambridge.

Buchan, B. 2002. 'Withstanding the tide of history: the Yorta Yorta case and indigenous sovereignty', Borderlands, 1 (2), (unpaginated), available at $<$ http://www.borderlandsejournal.adelaide.edu.au/vollno2_2002/ buchan_yorta.html $>$.

Cane, S. 2002. Pila Nguru: the Spinifex People, Fremantle Arts Centre Press, Fremantle.

Fraser, N. 1995. 'From redistribution to recognition? Dilemmas of justice in a “post-socialist" Age', New Left Review, (July/August): 68-93.

Fraser, N. and Honneth, A. 2003. Redistribution or Recognition? A Political-Philosophical Exchange, Verso, London.

Glaskin, K. 2003. 'Native title and the "bundle of rights" model: implications for the recognition of Aboriginal relations to country', Anthropological Forum, 13 (1): 67-88.

Lavery, D. 2003. 'A greater sense of tradition: The implications of the normative system principles in Yorta Yorta for native title determination applications', Murdoch University Electronic Journal of Law, 10 (4), December (unpaginated), available at $<$ http://www.murdoch.edu.au/elaw/issues/v10n4/lavery 104.html>.

Maaka, R. 1997. 'The politics of diaspora', paper presented at the Treaty of Waitangi: Maori Political Representation Future Challenges conference, Wellington, New Zealand, 1-2 May 1997.

Morgan, M. 2002. 'The Yorta Yorta experience, paper presented at the Outcomes and Possibilities Native Title Conference 2002, Geraldton, Western Australia, 4 September 2002.

Strelein, L. (nd) 'Comment on the High Court decision', available at $<$ http://ntru.aiatsis.gov.au/research/yorta_yorta/yorta_yorta.html $>$ [accessed 15 October 2006].

Strelein, L. 2005. 'Culture and commerce: the use of fishing traditions to prove native title', in L. Taylor, G. Ward, G. Henderson, R. Davies and L. Wallis (eds), The Power of Knowledge: the Resonance of Tradition, Aboriginal Studies Press, Canberra.

Taylor, C. 1992. Multiculturalism and 'the Politics of Recognition', Princeton University Press, Princeton. 